\title{
Ubiquitous Sensor Networks: Efisiensi Sistem Kontrol Cairan Infus Pasien Rawat Inap
}

\author{
BUDI RAHMADYA ${ }^{1}$, MIRA SISKA ${ }^{2}$, FAJRIL AKBAR ${ }^{3}$ \\ 1,2 Jurusan Sistem Komputer (Fakultas Teknologi Informasi, Universitas Andalas) \\ 3Jurusan Sistem Informasi (Fakultas Teknologi Informasi, Universitas Andalas) \\ Email: budi-r@fti.unand.ac.id
}

\begin{abstract}
ABSTRAK
Penelitian ini membahas tentang sistem kontrol cairan infus pada pasien dengan memanfaatkan teknologi sensor networks dan mikrokontroler arduino uno. Sensor yang digunakan adalah sensor Ultrasonik HC-SRO4 yang difungsikan untuk mendeteksi sisa cairan infus. Data yang terbaca oleh sensor dikirimkan menggunakan jaringan nirkabel/wireless dari Transmitter (TX) di ruang pasien ke Receiver $(R x)$ di ruang perawat dengan menggunakan modul wireless Xbee S2. Efisiensi dari sistem kontrol yang dibuat yaitu ketika sensor mendeteksi cairan infus mendekati batas habis cairan yang telah ditentukan maka motor yang berada pada selang infus akan berfungsi untuk menutup aliran cairan infus pada selang. Dari simulasi yang dilakukan, didapatkan hasil presentasi error ketinggian cairan infus sebesar $1.96 \%$ dan presentasi error volume cairan sebesar $2.16 \%$. Performa dari modul wireless Xbee S2 juga di ujicoba dengan mengirimkan data dari Xbee end device ke Xbee coordinator dalam penelitian ini.
\end{abstract}

Kata kunci: Infus, Sensor Networks, Sensor Ultrasonik HC-SR04, Xbee S2 dan Mikrokontroler Arduino Uno.

\begin{abstract}
This research discusses about intravenous fluids Control System on Patients, utilizing sensor network technology and Arduino Uno microcontroller. We used HC-SRO4 Ultrasonic sensors to detect the review time intravenous fluids. The sensors data is readable by transmitted using wireless network/wireless from Transmitter (TX) in Patients Into Space Receiver $(R X)$ at nurse room with using XBee wireless device S2. The efficiency of the control system were made, namely when the sensor detects the approaching limits of intravenous fluids discharged liquid that has been determined then the motor that was on the infus line will serve to close the infusion fluid flow in the line. In our simulations we found, the findings obtained Presentation intravenous fluids altitude error is $1.96 \%$ and presentations volume Liquid error is $2.16 \%$. The performance of network devices XBee S2 have been tried, wireless data from the XBee end devices coordinator in this research.
\end{abstract}

Keywords: Infusion, Sensor Networks, HC-SRO4 Ultrasonic Sensor, XBee S2 And Microcontroller Arduino Uno. 


\section{PENDAhUlUAN}

Kemajuan teknologi informasi saat ini dapat mempermudah manusia dalam meringankan pekerjaan melakukan aktifitas sehari-hari. Dalam bidang kesehatan penanganan pasien rawat inap di rumah sakit sangat penting untuk selalu di monitoring kondisi kesehatannya. Sebagai contoh penanganan pasien rawat inap di rumah sakit memerlukan tindakan cepat oleh dokter maupun perawat. Salah satu penanganan yang memerlukan tindakan cepat tersebut adalah penggantian cairan infus pada pasien rawat inap. Dengan memanfaatkan teknologi komputerisasi yang terhubung dengan perangkat elektronik seperti sensor, mikrokontroler, modul wireless dan lain-lain penanganan ini akan dapat di atasi dengan lebih cepat.

Dalam prakteknya, keterbatasan waktu, jarak, antara ruang pasien dan ruang perawat serta keterbatasan jumlah tenaga medis di rumah sakit/puskesmas dapat menyebabkan pasien terlambat ditanggulangi. Keterlambatan perawat dalam penggantian cairan infus ini dapat memberikan dampak negatif terhadap pasien dengan terjadinya komplikasi yaitu darah pasien tersedot naik ke selang infus dan darah tersebut dapat membeku pada selang infus. Kondisi ini tentu dapat membahayakan pasien itu sendiri.

Melihat kondisi seperti ini, teknologi wireless sensor network dapat dijadikan sebagai salah satu solusi dalam penanganan masalah tersebut. ZigBee merupakan jaringan komunikasi wireless dengan standar IEEE 802.15.4 (Zigbee Alliance, 2016). Standar ini memiliki fitur yang mudah dipelajari dan digunakan, serta performance komunikasi data yang baik antar node. Saat ini tren topik penelitian banyak menggunakan perangkat komunikasi ZigBee, seperti (Rasin, 2009) membahas tentang monitoring kwalitas air menggunakan sensor network. Peneliti fokus membahas tentang kondisi PH, kekeruhan dan suhu air. Tujuan dari penelitian ini adalah untuk meningkatkan efisiensi kerja, biaya dan peawatan yang lebih ekonomis yang di monitoring secara wireless menggunakan perangkat zigbee. (Fajriansyah, 2016) melakukan analisa dalam penelitiannya terhadap performa dari modul XBee Pro dan nRF24L01+ di dalam perancangan wireless sensor network, fokus dalam pembahasan sebagai modul transceiver. Dari simulasi yang dilakukan perolehan nilai untuk data rate XBee Pro menunjukan 27 Kbps dan nRF24L01+ sebesar 16 Kbps. Dalam uji coba kestabilan transmisi data di dalam ruangan XBee Pro memiliki performa lebih stabil di bandingkan nRF24L01+.

Kim memperkenalkan sistem monitoring dan control menggunakan zigbee secara real time. Peneliti fokus membahas tentang manajemen energi listrik yang digunakan pada sebuah rumah. Aplikasi yang dirancang yaitu berbasikan website dan mobile, aplikasi ini dapat mengontol pemakaian listrik yang digunakan yang bertujuan untuk menghemat biaya. (Kim, 2011) Armi membahas tentang sistem pemantauan ketersediaan air pada bak penampung sementara menggunakan Komunikasi Xbee S1. Dalam penelitian ini peneliti menggunakan sensor HC-SR04 untuk mengukur ketinggian air pada bak penampungan. Sistem yang dibuat menyajikan informasi secara real time. (Armi, 2015) Janos mengimplementasikan jaringan wireless menggunakan ZigBee untuk sistem monitoring kelembaban tanaman pada green house. Peneliti menggunakan mobile robot yang difungsikan sebagai station. Dalam simulasi alat, informasi dikirimkan secara broadcast. (Janos, 2010)

Dahoud membahas tentang uji kwalitas udara di daerah kota. Konsep dari penelitian ini adalah menggunakan Wireless Sensor Network (WSN) di dalam mengirimkan data secara 
wireless ke gateway. Peneliti melakukan uji coba terhadap kondisi CO, NO2 dan LPG. Data sensor dapar diakses oleh user secara real time melalui jaringan internet. (Dahoud, 2015) Garcia mengemukakan tentang system monitoring kesegaran buah-buahan dalam pengiriman. Peneliti memanfaatkan teknologi jaringan wireless untuk mengetahui kondisi kesegaran buah-buahan tersebut dengan menggunakan teknologi Xbow dan Xbee. (Garcia, 2008)

Dalam penelitian ini fokus membahas mengenai sistem monitoring dan mengontrol cairan infus pada pasien di rumah sakit/puskesmas. Pengujian yang dilakukan adalah untuk 2 (dua) buah transmitter yang dapat memberikan informasi kondisi cairan infus ke receiver. Ketika kondisi cairan infus sudah berada pada batas yang telah ditentukan motor servo yang terpasang pada infus akan bergerak menghentikan cairan pada selang. Kondisi seperti ini akan dikirimkan data secara wireless ke receiver yang ada di ruang perawat, sehingga penggantian infus segera ditangani oleh petugas. Modul wireless yang digunakan adalah Xbee S2 yang memiliki performa yang lebih baik dalam transmisi data untuk dalam ruangan. Sensor ultrasonik difungsikan untuk mendeteksi ketinggian cairan infus pada botol. Dalam penelitian ini perangkat lunak yang digunakan adalah XCT-U dan visual basic sebagai grafik interfacenya yang sudah terinstall di komputer ruang perawat.

\section{METODOLOGI PENELITIAN}

Cara kerja dari sistem kontrol ini adalah mendeteksi waktu yang dibutuhkan oleh sensor ultrasonik memancarkan gelombang dari transmitter ke receiver. Waktu yang dibutuhkan oleh sensor tersebut akan di konversi menjadi jarak dan data ini digunakan sebagai tinggi dari sisa cairan infus. Hasil dari proses ini, akan di tindak lanjuti oleh mikrokontroler menginstruksikan ke motor servo untuk bergerak menghentikan aliran infus sesuai batas yang telah ditentukan. Apabila sisa cairan sama dengan batas yang ditentukan, maka buzzer akan berbunyi, led berwarna merah akan hidup, dan motor bergerak menghentikan aliran infus yang menandakan cairan akan habis dan harus segera diganti. Begitu sebaliknya, apabila sisa cairan infus belum mencapai batas yang ditentukan, maka led berwarna hijau tetap menyala, buzzer tidak berbunyi dan aliran infus tetap mengalir pada selang. Dalam penelitian ini data yang di peroleh dari sensor dikirim menggunakan jaringan wireless dari ruang pasien ke pusat kontrol. Rangkaian dari sistem yang di rancang pada penelitian ini tergambar pada gambar 1 di bawah ini.

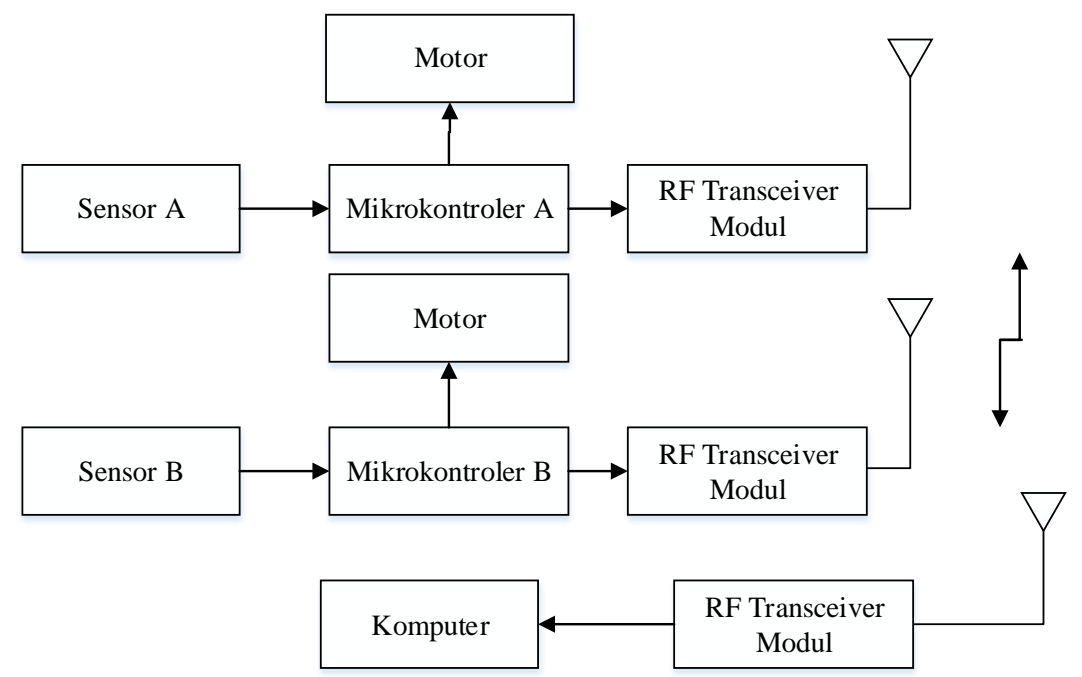

Gambar 1. Blok Diagram Sistem 
Berdasarkan gambar 1 diatas sensor A dan B berfungsi sebagai alat input yang berada di ruang pasien. Setiap sensor terpasang ke mikrokontroler dan motor. Sensor mendeteksi sisa cairan infus pada pasien, data ini akan di proses oleh mikrokontroler sehingga akan diperoleh sisa cairan infus pada masing-masing pasien. Motor berfungsi sebagai alat untuk mengatur aliran cairan pada selang infus. Sisa cairan infus dikirim melalui RF transceiver modul secara wireless menggunakan perangkat Xbee S2. Data yang dikirim ini akan diterima oleh komputer pada ruang kontrol.

Dalam perancangan software pada penelitian ini dapat dilihat melalui flowchart sistem program utama dan flowchart sistem program aplikasi pada komputer. Pada flowchart sistem program utama, menggambarkan alur program yang terdapat pada mikrokontroler untuk memproses data yang didapatkan dari sensor untuk selanjutnya akan dikirimkan ke komputer melalui jaringan wireless. Gambar 2 dibawah ini merupakan flowchart sistem program utama yang dibuat.

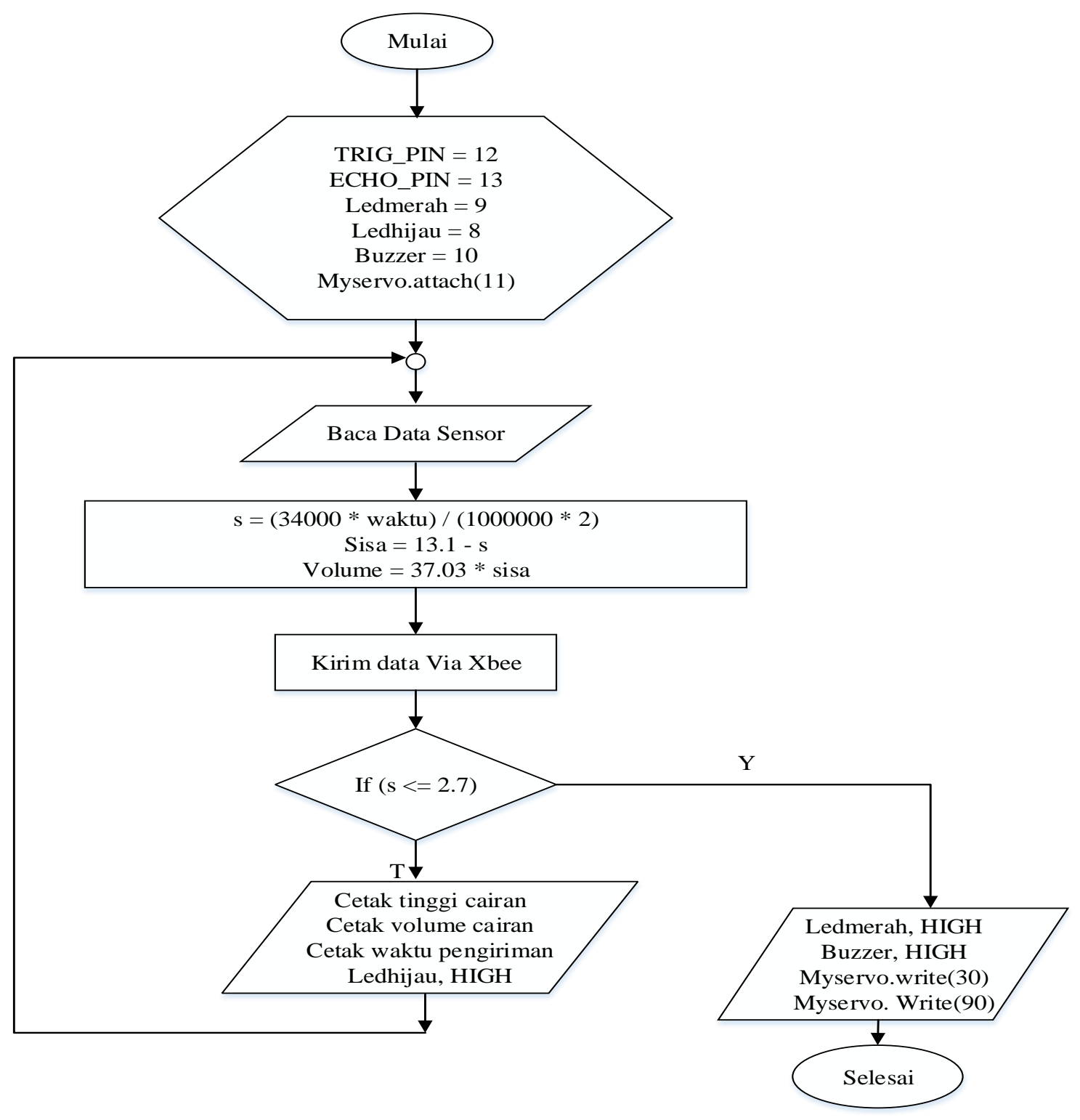

Gambar 2. Flowchart Sistem Program Utama 
Keterangan:

1. Memulai program

2. Deklarsi variable TRIG_PIN $=12$ adalah pin input, ECHO_PIN $=13$ adalah pin output, Ledmerah $=9$ adalah led penanda cairan sampai pada batas bawah (batas yang telah ditentukan), Ledhijau $=8$ adalah led penanda cairan masih batas aman, buzzer $=10$ adalah alarm untuk penanda cairan infus sampai pada batas bawah, Myservo.attach(11) adalah input pada motor servo

3. Sensor ultrasonik membaca data ketinggian cairan infus

4. Rumus untuk menghitung jarak sensor ke permukaan cairan adalah $s=(34000 *$ waktu) / $(1000000 * 2)$, rumus ketinggian sisa cairan adalah sisa $=13,1-\mathrm{s}$, dan rumus mencari volume cairan adalah volume $=37,03 *$ sisa

5. Data dari transmitter xbee dikirim ke receiver xbee pada komputer

6. Apabila tinggi cairan $<=2,7$, jika tidak maka cetak tinggi cairan, volume cairan dan waktu pengiriman, dan ledhijau aktif. Jika iya maka ledmerah, buzzer, dan motor servo akan aktif

7. Program selesai

Untuk flowchart sistem program aplikasi pada komputer merupakan program yang akan menampilkan sisa cairan infus pasien dan akan menampilkan tanda peringatan cairan infus berada di posisi batas bawah. Gambar 3 dibawah ini merupakan flowchart sistem program aplikasi yang dibuat.

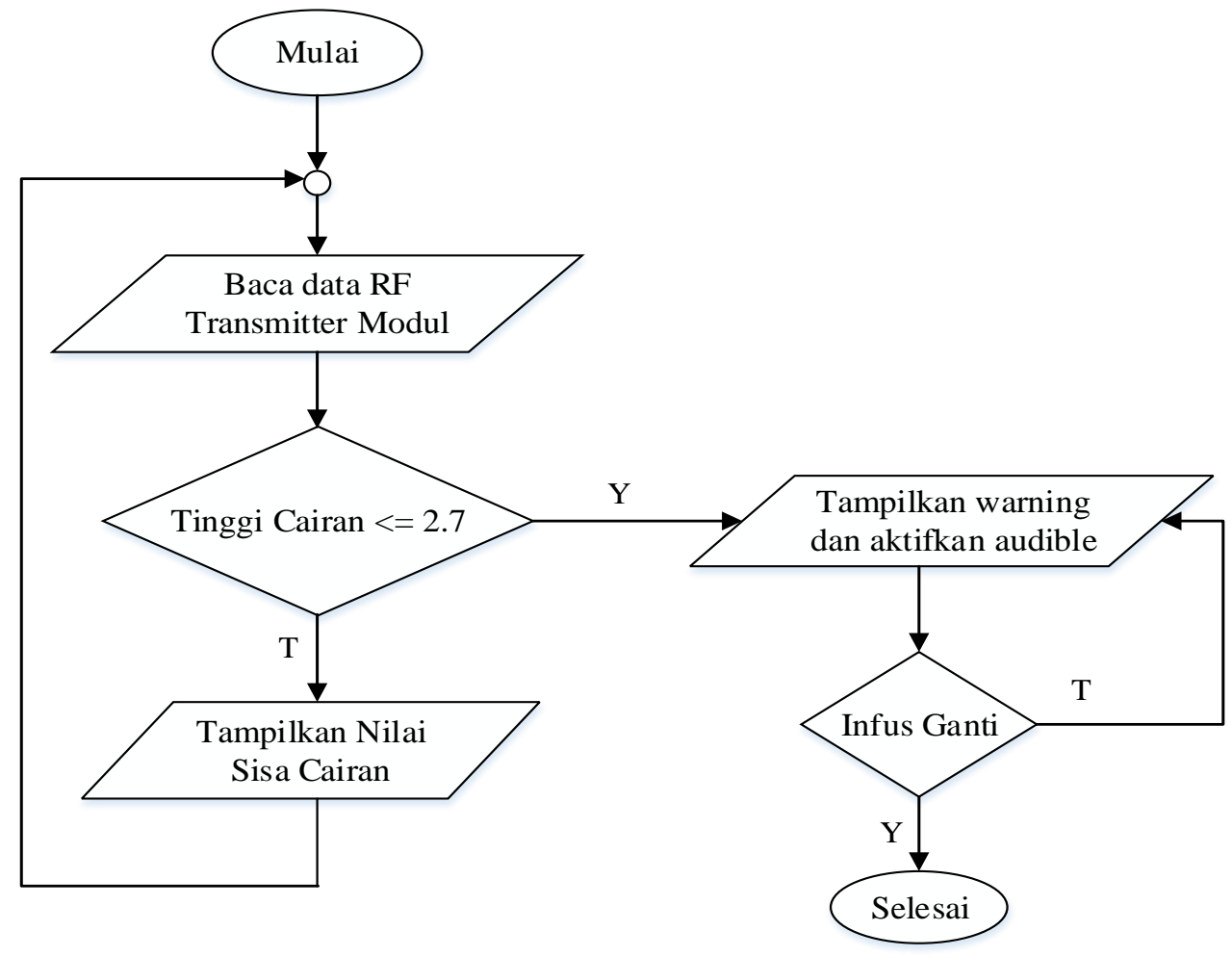

Gambar 3. Flowchart Sistem Program Aplikasi

Keterangan:

1. Memulai program

2. Data dari Xbee transmitter diterima pada xbee receiver

3. Jika tinggi cairan sama dengan 2,7 maka peringatan dan alarm akan aktif. Jika tidak maka interface hanya menampilkan sisa cairan infus 
4. Jika alarm aktif, maka botol infus harus diganti, jika tidak maka alarm akan tetap berbunyi.

5. Program selesai.

\section{HASIL DAN PEMBAHASAN}

Sistem kontrol sisa cairan infus menggunakan jaringan wireless dibuat untuk memberikan efisiensi waktu bagi dokter/perawat dalam pengontrolan sisa cairan infus pasien. Dari simulasi yang dilakukan pengujian mengacu ke: 1. Pengujian Sensor ultrasonic HC-SR04, 2. Pengujian XBee S2, 3. Pengujian katup infus, 4. Pengujian keseluruhan

\subsection{Pengujian Sensor Ultrasonik HC-SR04}

Pengujian sensor ultrasonik dilakukan dengan cara membaca waktu yang diperoleh antara pengiriman data dari transmitter ke receiver, data yang di dapat akan dikonversi menjadi tinggi cairan, data ini akan ditampilkan pada serial monitor program arduino uno. Proses penghitungan ketinggian sisa cairan pada tabung infus dapat dilihat pada gambar 4 berikut:

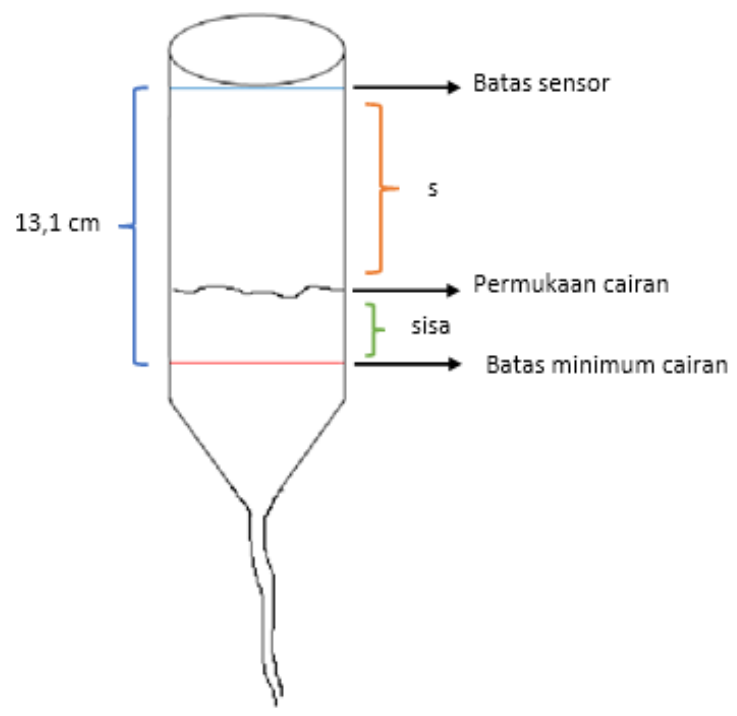

\section{Gambar 4. Perhitungan Sisa Cairan Infus}

Menghitung sisa cairan infus menggunakan rumus sebagai berikut :

$$
\begin{aligned}
& \mathrm{s}=(34.000 * \text { waktu }) /(1000000 * 2) \\
& \text { sisa }=13.1 \mathrm{~s}
\end{aligned}
$$

Keterangan:

$$
\begin{array}{lll}
\mathrm{s} & : & \text { Jarak dari sensor ke permukaan cairan }(\mathrm{cm}) \\
\text { Waktu } & : \begin{array}{l}
\text { Waktu tempuh dua kali lintasan gelombang } \\
\end{array} \\
\text { Sisa } & : \text { Ketrasonik }(\mu \mathrm{s}) \\
13.1 & : \text { Jarak sensor ke set point }(\mathrm{cm}) \\
34.000: & \text { Kecepatan suara pada }(\mathrm{cm} / \mathrm{s}) \\
2 & : \begin{array}{l}
\text { Faktor pembagi karena gelombang ultrasonik } \\
\text { menempuh dua lintasan }
\end{array}
\end{array}
$$

Menghitung volume air pada tabung infus berdasarkan ketinggian air dengan rumus: 


$$
\text { volume }=37.03 * \text { sisa }
$$

Keterangan:

$$
\begin{array}{lll}
\text { Volume } & : & \text { Volume sisa cairan infus }(\mathrm{mL}) \\
37.03 & : & \text { Jumlah cairan infus dalam satu } \\
& \text { cm tabung infus }(\mathrm{mL})
\end{array}
$$

Dalam mencari nilai error dari pengukuran ketinggian air menggunakan rumus:

$$
\text { Error }=\frac{\text { nilai } \text { yang diinginkan }- \text { nilai terbaca }}{\text { nilai yang diinginkan }} \times 100 \%
$$

Dalam pengujian sensor ultrasonik HC-SR04 dilakukan dengan cara pengambilan data sebanyak 10 kali. Tabel 1 dibawah adalah pengujian ketinggian dari sensor ke permukaan cairan infus dan pengukuran secara langsung dilakukan dengan menggunakan alat bantu penggaris. Pada pengujian persentase error yang didapatkan dari perbandingan ketinggian cairan yang terukur secara langsung dengan pengukuran menggunakan sensor adalah 1.96 $\%$.

Tabel 1. Pengujian ketinggian cairan infus

\begin{tabular}{|c|c|c|c|}
\hline Data ke & Jarak pada sensor $\mathbf{( c m})$ & Jarak sebenarnya $\mathbf{( c m})$ & Error $(\%)$ \\
\hline 1 & 2.7 & 2.7 & 0 \\
\hline 2 & 2.79 & 2.7 & 3.33 \\
\hline 3 & 2.6 & 2.7 & 3.7 \\
\hline 4 & 2.74 & 2.7 & 1.48 \\
\hline 5 & 2.64 & 2.7 & 2.22 \\
\hline 6 & 2.74 & 2.7 & 1.48 \\
\hline 7 & 2.6 & 2.7 & 3.7 \\
\hline 8 & 2.74 & 2.7 & 1.48 \\
\hline 9 & 2.64 & 2.7 & 2.22 \\
\hline 10 & 2.7 & 2.7 & 0 \\
\hline \multicolumn{2}{|c|}{ Rata-rata error (\%) } \\
\hline
\end{tabular}

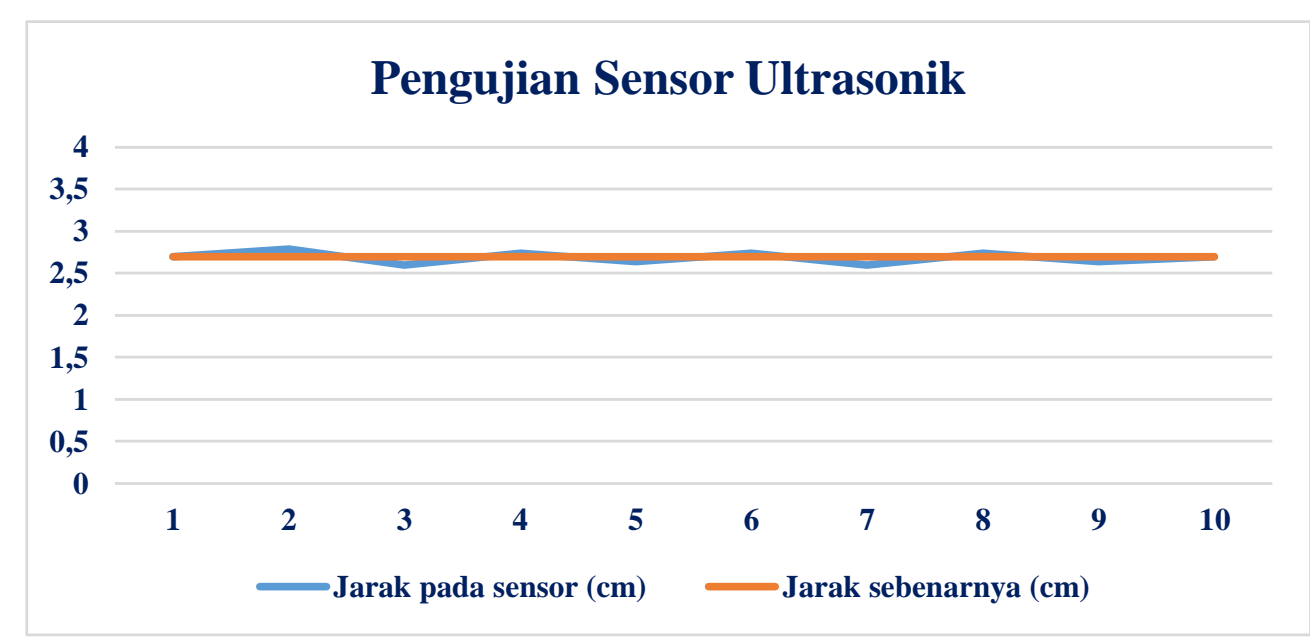

Gambar 5. Grafik Pengujian Sensor Ultrasonik HC-SR04

Tabel 2 dibawah adalah hasil pengujian volume cairan infus menggunakan sensor dan pengukuran secara langsung. Persentase error volume cairan dengan pengukuran langsung 
dan menggunakan sensor adalah $2.16 \%$. Pengambilan data dilakukan sebanyak 10 kali percobaan.

Tabel 2. Pengujian volume cairan infus

\begin{tabular}{|c|c|c|c|}
\hline Data ke & Volume (mL) & Volume Sebenarnya $(\mathbf{m L})$ & Error $(\%)$ \\
\hline 1 & 100.16 & 100 & 0.16 \\
\hline 2 & 101.45 & 100 & 1.45 \\
\hline 3 & 103.38 & 100 & 3.38 \\
\hline 4 & 96.3 & 100 & 3.7 \\
\hline 5 & 101.45 & 100 & 1.45 \\
\hline 6 & 97.59 & 100 & 2.41 \\
\hline 7 & 101.45 & 100 & 1.45 \\
\hline 8 & 96.3 & 100 & 3.7 \\
\hline 9 & 101.45 & 100 & 1.45 \\
\hline 10 & 97.59 & 100 & 2.41 \\
\hline \multicolumn{2}{|c|}{ Rata-rata error (\%) } \\
\hline
\end{tabular}

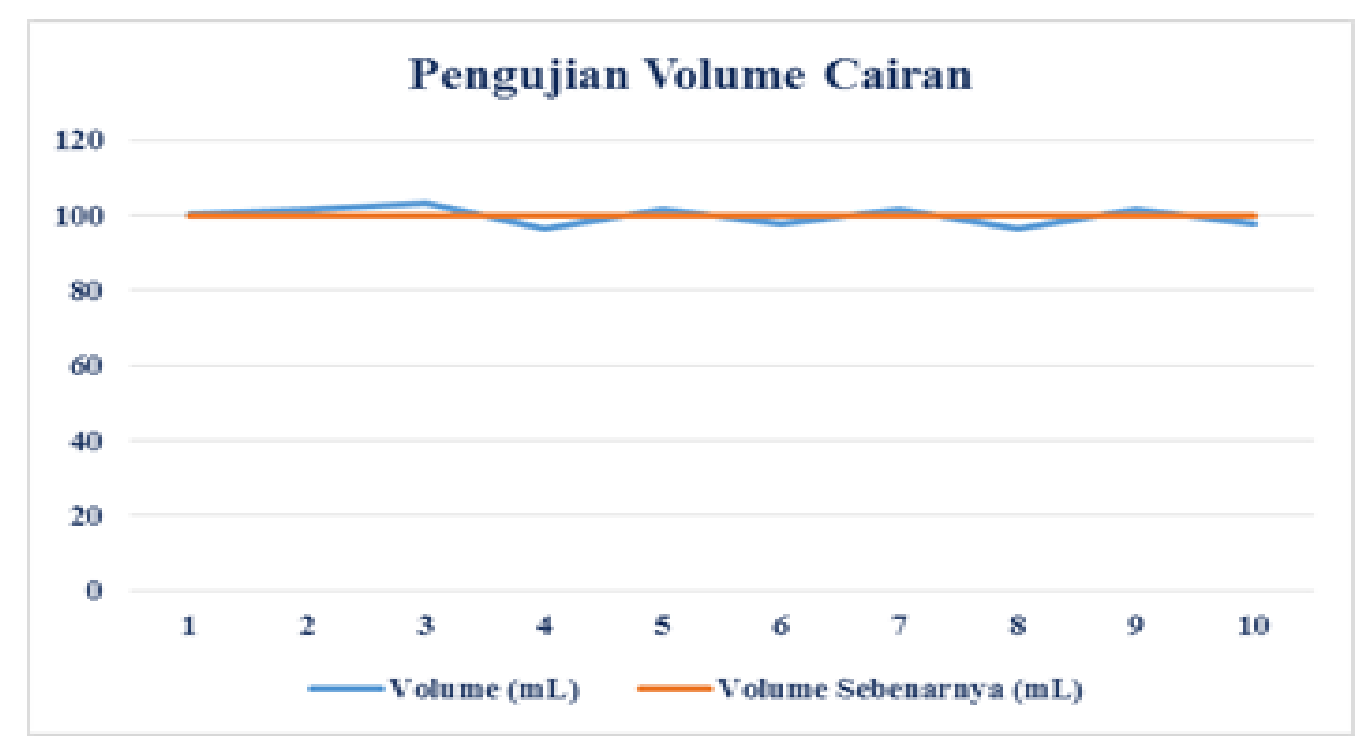

Gambar 6. Grafik Pengujian Volume Cairan Infus

\subsection{Pengujian Komunikasi Jaringan Xbee $\mathbf{S 2}$}

Pengujian dilakukan dengan 2 (dua) buah end device dan saling terkoneksi dengan Xbee coordinator pada ruang kontrol. Gambar 5 dibawah ini adalah rangkaian komunikasi jaringan Xbee S2 yang dibuat. 


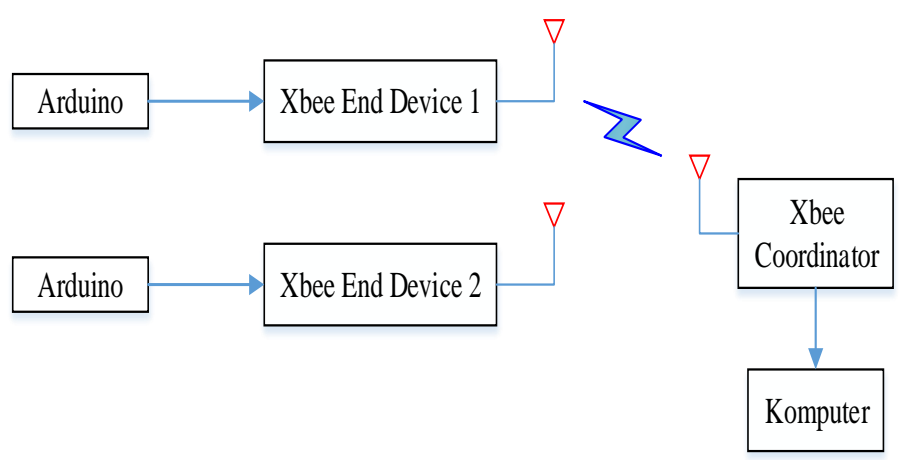

Gambar 7. Rangkaian Komunikasi Jaringan Xbee S2

Hasil pengujian komunikasi jaringan Xbee $S 2$ end device 1 dengan xbee coordinator dapat dilihat pada table 1. Data dikirim dalam bentuk karakter dari Xbee end device 1 dan diterima oleh Xbee coordinator berupa data dalam bilangan ASCII. Pengujian komunikasi jaringan Xbee S2 ini dilakukan dengan 10 (sepuluh) kali pengujian.

\section{Tabel 3. Pengujian Komunikasi Jaringan Xbee S2 end device 1 dengan Xbee Coordinator}

\begin{tabular}{|c|c|c|}
\hline $\begin{array}{c}\text { Data } \\
\text { ke }\end{array}$ & Xbee S2 End Device 1 & Xbee Coordinator \\
\hline 1 & 111.112 .113 & $3131312 \mathrm{E} 313132$ 2E 313133 OD \\
\hline 2 & 114.115 .116 & 313134 2E 313135 2E 313136 OD \\
\hline 3 & 117.118 .119 & 313137 2E 313138 2E 313139 OD \\
\hline 4 & 101.002 .100 & $3130312 \mathrm{E} 303032$ 2E 313030 0D \\
\hline 5 & 102.003 .200 & 313032 2E 303033 2E 323030 OD \\
\hline 6 & 102.003 .200 & 313032 2E 303033 2E 323030 OD \\
\hline 7 & 111.112 .113 & $3131312 \mathrm{E} 313132$ 2E 313133 OD \\
\hline 8 & 111.112 .113 & $3131312 \mathrm{E} 313132$ 2E 313133 OD \\
\hline 9 & 114.115 .116 & $3131342 E 3131352 E 313136$ OD \\
\hline 10 & 101.002 .100 & 313031 2E 303032 2E 313030 0D \\
\hline
\end{tabular}

Hasil pengujian komunikasi jaringan Xbee $S 2$ end device 2 dengan xbee coordinator dapat dilihat pada tabel 2. Data dikirim secara acak dari Xbee S2 end device 2 dan diterima oleh xbee coordinator berupa bilangan ASCII. Pengambilan data dilakukan pada 10 (sepuluh) kali pengujian.

Tabel 4. Pengujian Komunikasi Xbee end device 2 dengan Xbee Coordinator

\begin{tabular}{|c|c|c|}
\hline $\begin{array}{c}\text { Data } \\
\text { ke }\end{array}$ & Xbee S2 End Device 2 & Xbee Coordinator \\
\hline 1 & SISKOM10 & 534953 4B 4F 4D 3130 0D \\
\hline 2 & 1010451011 & $313031303435313031310 D$ \\
\hline 3 & Computer & 6B 6F 6D 7075746572 OD \\
\hline 4 & Program & $70726 \mathrm{~F} 677261$ 6D 0D \\
\hline 5 & 29-09-1992 & $32392 \mathrm{D} 3039$ 2D 31393932 0D \\
\hline 6 & SK_UNAND & 53 4B 5F 55 4E 41 4E 44 0D \\
\hline 7 & 12345678 & 3132333435363738 0D \\
\hline 8 & 1010451011 & 31303130343531303131 OD \\
\hline 9 & 1010451011 & 31303130343531303131 OD \\
\hline 10 & Program & $7026 \mathrm{~F} 677261$ 6D OD \\
\hline
\end{tabular}




\subsection{Pengujian Sistem Penutup Katup Infus}

Dalam pengujian sistem penutup katup infus ini motor servo di program pada sudut $30^{\circ}$, motor servo berfungsi untuk menghentikan cairan pada selang infus. Tabel 3 di bawah ini adalah hasil dari pengujian pergerakan motor servo pada selang infus.

Tabel 5. Pengujian pergerakan motor servo

\begin{tabular}{|c|c|c|c|}
\hline No. & Sudut $\mathbf{(}^{\circ} \mathbf{)}$ & Delay & Kondisi Cairan \\
\hline 1 & 30 & 10000 & Berhenti Menetes \\
\hline 2 & 30 & 5000 & Menetes \\
\hline 3 & 30 & 1000 & Menetes \\
\hline 4 & 30 & 100 & Menetes \\
\hline 5 & 30 & 10 & Menetes \\
\hline
\end{tabular}

\subsection{Pengujian Keseluruhan}

Proses pengujian sistem secara keseluruhan dalam pengontrolan cairan infus dapat dilihat pada skema pengujian Gambar 8 dibawah ini:

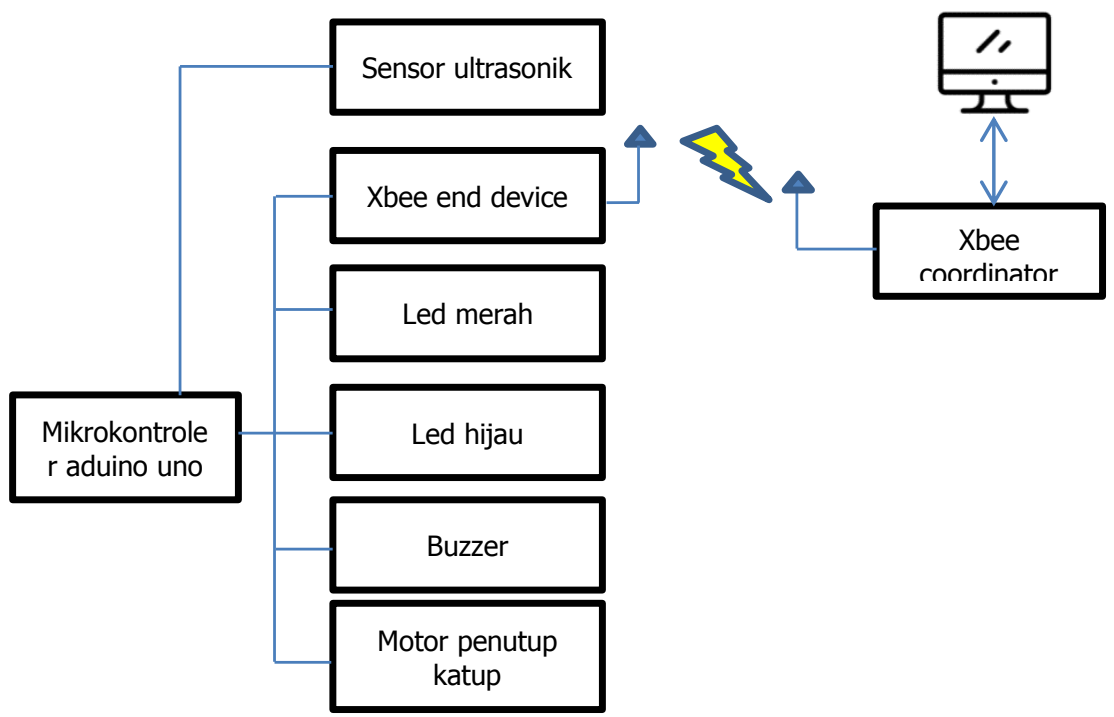

Gambar 8. Skema Pengujian Sistem Secara Keseluruhan

Pengujian sistem secara keseluruhan dilakukan untuk dua infus/pasien (infus 1 dan 2). Pengujian dilakukan dengan menghitung nilai tinggi cairan, volume cairan, kondisi led, kondisi buzzer, dan kondisi motor. Ketinggian dan volume cairan akan diproses oleh mikrokontroler arduino uno. Jika tinggi cairan infus dibawah $100 \mathrm{~mL}$, maka lampu led hijau akan hidup, sistem warning pada buzzer akan off (tidak berbunyi) dan motor servo tidak akan menghentikan aliran cairan infus. Jika tinggi cairan infus berada pada posisi yang telah ditentukan (leher botol), maka lampu led merah akan hidup, sistem warning pada buzzer akan on (berbunyi) menandakan cairan infus akan habis dan motor servo akan bergerak menghentikan selang infus. 
Tabel 6. Pengujian Keseluruhan pada Infus 1

\begin{tabular}{|c|c|c|c|c|c|c|c|c|}
\hline Data & Tinggi & Volume & \multicolumn{2}{|c|}{ Kondisi Led } & \multicolumn{2}{c|}{ Kondisi Buzzer } & \multicolumn{2}{c|}{ Kondisi Motor } \\
\cline { 5 - 9 } & $\mathbf{( c m})$ & $\mathbf{( m L})$ & Normal & Actual & Normal & Actual & Normal & Actual \\
\hline 1 & 10.39 & 384.74 & Hijau & Hijau & Off & Off & Off & Off \\
\hline 2 & 9.98 & 369.56 & Hijau & Hijau & Off & Off & Off & Off \\
\hline 3 & 9.56 & 354.01 & Hijau & Hijau & Off & Off & Off & Off \\
\hline 4 & 9.37 & 346.97 & Hijau & Hijau & Off & Off & Off & Off \\
\hline 5 & 8.83 & 326.97 & Hijau & Hijau & Off & Off & Off & Off \\
\hline 6 & 8.36 & 309.57 & Hijau & Hijau & Off & Off & Off & Off \\
\hline 7 & 8.36 & 309.57 & Hijau & Hijau & Off & Off & Off & Off \\
\hline 8 & 7.13 & 264.02 & Hijau & Hijau & Off & Off & Off & Off \\
\hline 9 & 6.76 & 250.32 & Hijau & Hijau & Off & Off & Off & Off \\
\hline 10 & 5.56 & 205.89 & Hijau & Hijau & Off & Off & Off & Off \\
\hline 11 & 5.35 & 198.11 & Hijau & Hijau & Off & Off & Off & Off \\
\hline 12 & 4.5 & 166.64 & Hijau & Hijau & Off & Off & Off & Off \\
\hline 13 & 3.79 & 140.34 & Hijau & Hijau & Off & Off & Off & Off \\
\hline 14 & 3.41 & 126.27 & Hijau & Hijau & Off & Off & Off & Off \\
\hline 15 & 2.7 & 99.98 & Merah & Merah & On & On & On & On \\
\hline
\end{tabular}

Gambar 9 adalah grafik dari hasil pengujian sistem secara keseluruhan untuk infus 1 .

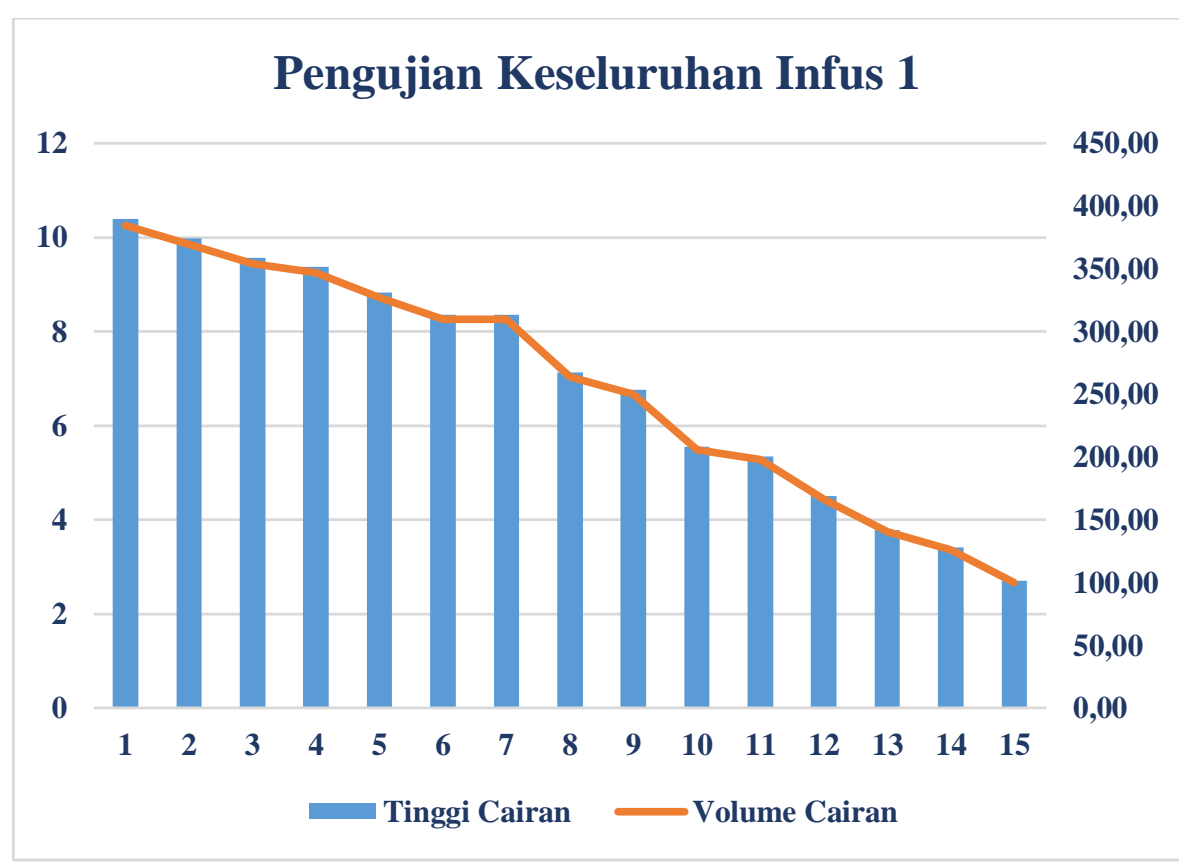

\section{Gambar 9. Grafik Pengujian Sistem Secara Keseluruhan Infus 1}

Pada pengujian sistem secara keseluruhan infus 2, proses pengujian sama seperti pengujian infus 1. Hasil pengujian keseluruhan pada infus 2 dapat dilihat pada Tabel 7 : 
Tabel 7. Pengujian Sistem Secara Keseluruhan pada Infus 2

\begin{tabular}{|c|c|c|c|c|c|c|c|c|}
\hline \multirow{2}{*}{$\begin{array}{c}\text { Data } \\
\text { Ke- }\end{array}$} & \multirow{2}{*}{$\begin{array}{l}\text { Tinggi } \\
(\mathbf{c m})\end{array}$} & \multirow{2}{*}{$\begin{array}{c}\text { Volume } \\
(\mathrm{mL})\end{array}$} & \multicolumn{2}{|c|}{ Kondisi Led } & \multicolumn{2}{|c|}{ Kondisi Buzzer } & \multicolumn{2}{|c|}{ Kondisi Motor } \\
\hline & & & Normal & Actual & Normal & Actual & Normal & Actual \\
\hline 1 & 8.38 & 310.31 & Hijau & Hijau & Off & Off & Off & Off \\
\hline 2 & 8.01 & 296.61 & Hijau & Hijau & Off & Off & Off & Off \\
\hline 3 & 7.54 & 279.21 & Hijau & Hijau & Off & Off & Off & Off \\
\hline 4 & 7.44 & 275.50 & Hijau & Hijau & Off & Off & Off & Off \\
\hline 5 & 7.39 & 273.65 & Hijau & Hijau & Off & Off & Off & Off \\
\hline 6 & 6.66 & 246.62 & Hijau & Hijau & Off & Off & Off & Off \\
\hline 7 & 5.72 & 211.81 & Hijau & Hijau & Off & Off & Off & Off \\
\hline 8 & 5.7 & 211.07 & Hijau & Hijau & Off & Off & Off & Off \\
\hline 9 & 5.28 & 195.52 & Hijau & Hijau & Off & Off & Off & Off \\
\hline 10 & 4.55 & 168.49 & Hijau & Hijau & Off & Off & Off & Off \\
\hline 11 & 4.45 & 164.78 & Hijau & Hijau & Off & Off & Off & Off \\
\hline 12 & 4.29 & 158.86 & Hijau & Hijau & Off & Off & Off & Off \\
\hline 13 & 4.03 & 149.23 & Hijau & Hijau & Off & Off & Off & Off \\
\hline 14 & 3.51 & 129.98 & Hijau & Hijau & Off & Off & Off & Off \\
\hline 15 & 2.7 & 99.98 & Merah & Merah & On & On & On & On \\
\hline
\end{tabular}

Gambar 10 dibawah ini adalah grafik dari hasil pengujian sistem secara keseluruhan pada infus 2.

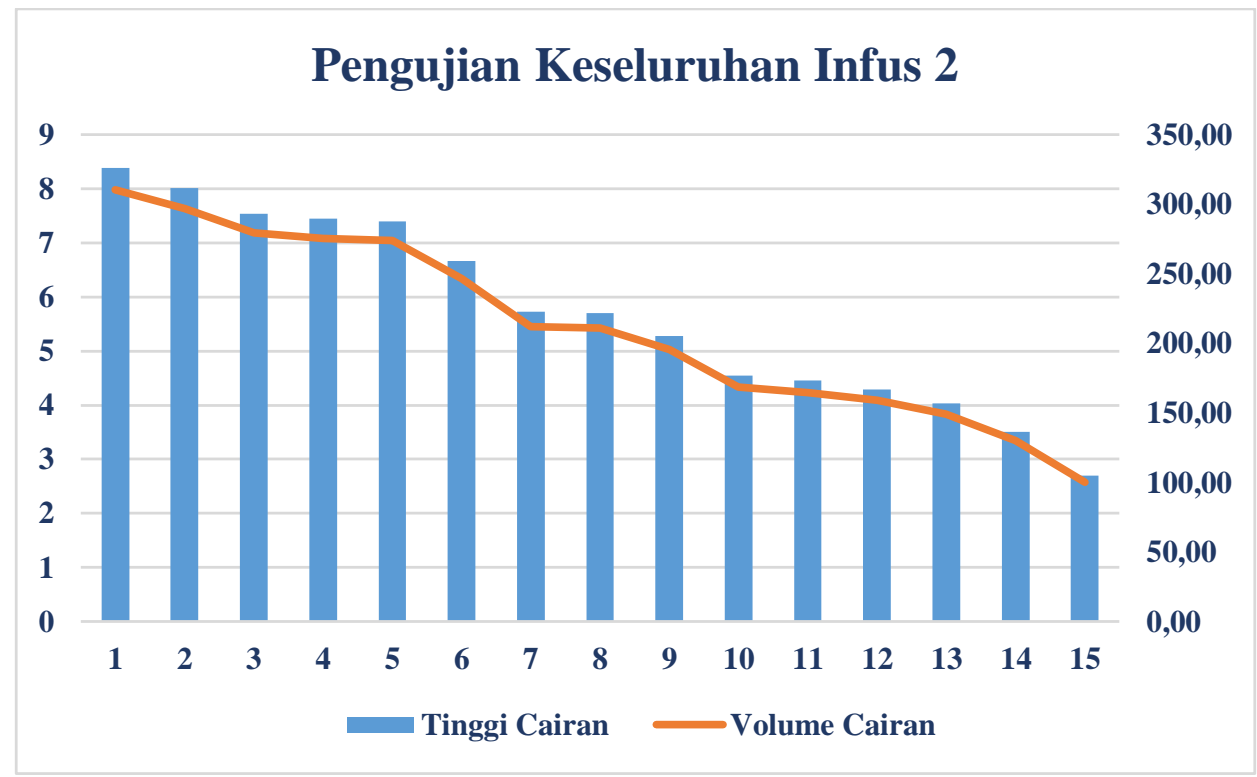

Gambar 10. Grafik Pengujian Sistem Secara Keseluruhan Infus 2

Dari pengujian keseluruhan pada infus 1 dan infus 2 ini, didapatkan hasil perbandingan antara kondisi normal dan actual adalah sama, sistem dapat bekerja dengan baik pada sistem kontrol sisa cairan infus dan pengendalian aliran infus. 
Pengiriman data dari ke 2 (dua) end device dan diterima pada komputer di ruang perawat ditampilkan pada aplikasi visual basic. Gambar 11 dibawah ini adalah screen capture dari sistem pengujian keseluruhan.

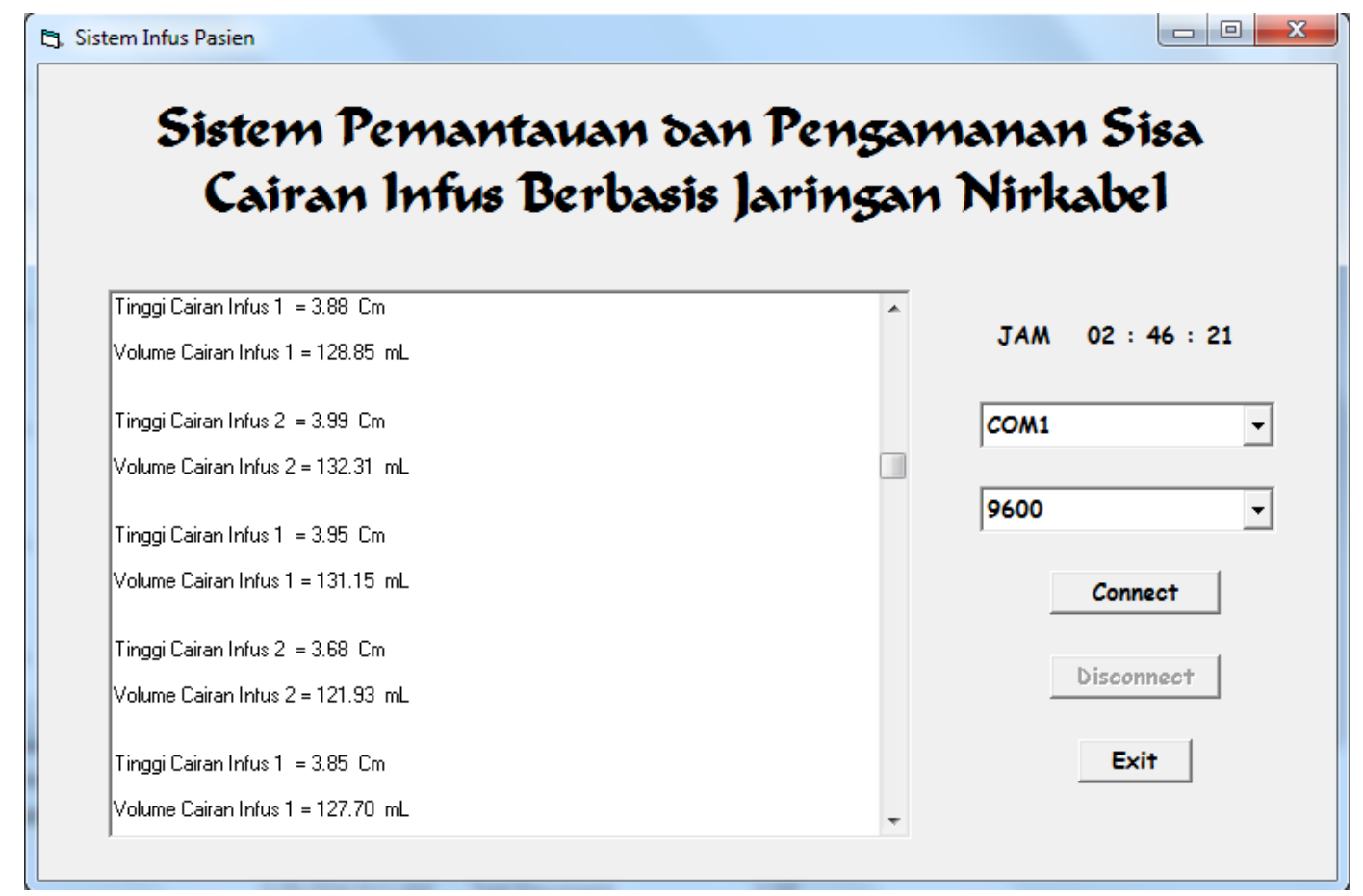

Gambar 11. Sistem Pengujian Keseluruhan

\section{KESIMPULAN}

Dari simulasi yang telah dilakukan didapat persentasi error ketinggian cairan infus $1.96 \%$ dan persentasi error volume sisa cairan infus yaitu $2.16 \%$. Dalam penelitian ini kami juga melakukan pengujian komunikasi jaringan Xbee $S 2$ end device 1 dan 2 dengan xbee coordinator yang telah dirancang. Simulasi dilakukan mengacu kepada 2 (dua) jenis data yang dikirim yaitu 1). Data dalam bentuk karakter dan 2). Data acak (karakter dan numberik). Hasil dari ke 2 (dua) simulasi ini menghasilkan output berupa bilangan American Standard Code for Information Interchange (ASCII). Dalam penelitian ini juga dilakukan pengujian secara keseluruhan untuk hasil dari LED, Buzzer dan Motor. Hasil yang didapat, sistem dapat bekerja dengan baik yaitu menunjukan data yang sama. Dalam pengembangan penelitian lebih lanjut, peneliti akan melakukan ujicoba dan analisa terhadap kecepatan dari cairan infus dengan menggunakan sensor flow.

\section{DAFTAR RUJUKAN}

Zigbee Alliance. (2016). Dipetik dari Website http://www.zigbee.org/.

Rasin, Z., \& Abdullah, M, R. (2009). Water Quality Monitoring System Using Zigbee Based Wireless Sensor Network. International Journal of Engineering \& Technology IJET Vol: 9 No: 10. 
Fajriansyah, B., Ichwan, M., \& Susana, T. (2016). Evaluasi Karakteristik XBee Pro dan nRF24LO1+ sebagai Transceiver Nirkabel. Jurnal Elkomika. 4(1) : 83 - 97.

Kim, W, H., Lee, S., \& Hwang, J. (2011). Real-time Energy Monitoring and Controlling System based on ZigBee Sensor Networks. International Symposium on Intelligent Systems Techniques for Ad hoc and Wireless Sensor Networks (IST-AWSN). Procedia Computer Science 5.

Armi, S., Andrizal., Rahmadya, B., \& Derisma. (2015). Prototipe Pemantauan Ketersediaan Air Pada Bak Penampung Sementara Menggunakan Komunikasi Xbee S1. Seminar Nasional Teknologi Informasi dan Komunikasi Terapan (SEMANTIK).

Janos, S., Martinovic, G., \& Matijevics, I. (2010). WSN Implementation in the Greenhouse Environment Using Mobile Measuring Station. International Journal of Electrical and Computer Engineering Systems. 1(1).

Dahoud, A, A., Fezari, M., Jannoud, I., \& Rawashdeh, A, T. (2015). Monitoring Metropolitan City Air-quality Using Wireless Sensor Nodes based on ARDUINO and XBEE. Proceedings of The International Conference on Circuits, Systems, Signal Processing, Communications and Computers (CSSCC 2015).

Garcia, L, R., Barreiro, P., \& Robla, J, I. (2008). Performance of ZigBee-Based wireless sensor nodes for real-time monitoring of fruit logistics. Elsevier. Journal of Food Engineering. 87: $405-415$. 